\title{
Organic Farming in Poland and the Czech Republic - Comparative Analysis
}

\author{
Anna Sylwia KOWALSKA ${ }^{1}$, Klaudia GURKOWA ${ }^{1}$ and Jaroslav KOVÁRNÍK ${ }^{2, *}$ \\ 1 Wroclaw University of Economics and Business, Wrocław, Poland; anna.kowalska@ue.wroc.pl; \\ klaudia.gurkowa@ue.wroc.pl \\ 2 University of Hradec Kralove, Hradec Kralove, Czech Republic; jaroslav.kovarnik@uhk.cz \\ * Correspondence: jaroslav.kovarnik@uhk.cz
}

\begin{abstract}
The aim of the article was to assess organic farming in Poland and in the Czech Republic and the changes that occurred in these countries after their accession to the European Union. The study used statistical materials published by FIBL, IFOAM and Eurostat, as well as Czech reports on the state of organic farming. The basic time range of the data covers the years 2000-2018. The article uses basic methods of statistical data analysis, i.e. Pearson correlation, trend lines, and dynamics indicators. Analyses showed changes in these countries in the area, in the number of producers, and in processing plans of organic food. Despite the significant increase in the area of organic farming in Poland, the share of these crops in relation to the total area of agricultural crops in the country is small. The country that develops very dynamically in this respect is the Czech Republic. In Poland, a downward trend has been noticed since 2014, both in respect to the cultivated area and the number of organic producers. However, the increase is visible in the number of organic processing plants. In the Czech Republic, the residents' expenses on organic food are also noticeably higher than in Poland.
\end{abstract}

Keywords: organic farming; organic food; development; Poland; the Czech Republic

JEL Classification: Q15; Q18; Q56

\section{Introduction}

Organic farming is a broadly understood, but logically complex system of managing the whole production (Barłowska and Wolanciuk 2017). It applies to both plant and animal base. The basic issue that characterizes this type of production is maintaining a number of strictly defined standards (IFOAM, 2005). Such factors (e.g. a high degree of biodiversity, or very good animal husbandry) must necessarily be presented on ecologically certified farms. Importantly, all production should be based only on natural methods. Organic farming does not contain GMOs, pesticides, synthetic fertilizers, growth regulators, or any feed additives. Any mechanization is also limited. Soil fertility is ensured by means of a well-planned crop rotation. The choice of plants (their species and varieties) and animals (their species and races) is one of the basic principles of managing organic farming. All of that contributes to achieving the main goals, i.e. environmental protection as well as high-quality plant and animal products (Rigby and Câceres 2001). In this way, it can be argued that organic farming can be profitable (Kiełbasa 2015). Despite the fact that the yields are usually significantly lower and the time of livestock farming much longer, the prices of manufactured products are also much higher than those from conventional farms. Therefore, the fact is that organic farming has been undergoing significant development and growth for several years. It is worth noting that this is especially noticeable in the member states of the European Union.

The development and growth of organic farming would not be possible without properly formulated and enforced legal regulations. In the past, it was a responsibility of an EU working group. Currently, an important role in creating legislative framework is played by The International Federation of Organic Agriculture Movements (IFOAM). It was formally established in February 2000. Two years later, it was registered in Sweden as an international non-profit organization. Since 2003, its headquarters have been located in Brussels (see http://www.ifoam-eu.org/). From this moment it has been this institution that sets international rules for organic farming. It defines its goals and 
framework of functioning. Constantly, to the present, this is the legislative base and a reference for the formulation of national legal provisions. The creation of the 'Europe 2020' Strategy, described by Kowalska and Kovárník (2019), presenting sustainable development (i.e. supporting a resourceefficient economy, more environmentally friendly and more competitive as one of its three mutually reinforcing priorities) has had a significant impact on the development of organic farming in the European Union, and thus also in the new Member States.

The purpose of the article was to make a comparative analysis of organic farming in Poland and the Czech Republic over the years 2000-2018. These countries were chosen intentionally, as representatives of the Eastern Bloc and important trading partners. These countries are close neighbours and members of the European Union, which they joined at the same time (Kowalska et. al. 2017). However, it should be noted that both the structure and conditions for conducting agricultural activity in both countries differ significantly (Olszańska and Dittrichová 2018).

It is intended to pay particular attention to the impact of these countries' accession to the European Union on the analysed issue. The differences and similarities included in the study concern the most important, in the authors' opinion, issues related to organic farming.

\section{Methodology}

The study used statistical materials published in the form of reports and statistics by FIBL and IFOAM, as well as Eurostat. The data sheets regarding organic farming published by Poland and the Czech Republic were also used. The subject of the analysis were two neighbouring countries that joined the European Union at the same time, i.e. Poland and the Czech Republic. The basic data interval covers the years 2000-2018 (some analyses, due to lack of data, end in 2017). The study used the method of literature discussion, based on both Polish and foreign literature on the subject. The essence of this method is to relate the diagnosed problem to existing knowledge. It shall help significantly address all kinds of issues related to organic farming in the above mentioned neighbouring countries. The article uses basic methods of statistical data analysis, i.e. Pearson's correlation, trend lines, dynamics indicators, and cluster analysis. For the discussed countries, time series of the number of organic farms, their area, and the share of the area of organic farms in the total area of agricultural land were presented. For them, a trend function line and a determination coefficient $\mathrm{R}^{2}$ were determined. It was assumed that for $\mathrm{R}^{2} \geq 0.70$ the fit of functions to empirical data is very strong.

\section{Results and Discussion}

Organic farming in Poland and the Czech Republic, after accession of these countries to the European Union, has begun to develop. This development was more or less intense in each of these countries. The analysis of the area of organic farming indicates that it developed more dynamically in Poland, which was especially visible after 2004 (Fig. 1). In the years 2000-2018, it increased more than 21 times, where the largest increase by almost $710 \%$ (from 83,000 ha to almost 670,000 ha) was recorded in the years 2004-2013. After 2013, the area of these crops decreased by over $27.6 \%$ (during the last 5 years, i.e. from 670,000 to 485,000 ha). This trend continues. In Poland, the area of organic farming grew annually by over 37.55 thousand ha in the years 2000-2018, with a very good trend line fit $\left(R^{2}=0.78\right)$. In the Czech Republic, the area of organic farming grew more than three times in the analysed period (from 166,000 ha to over 520,000 ha). In the case of this country, the average annual increase in area during the period under review was over 20.25 thousand ha, with a very good fit $\left(\mathrm{R}^{2}=0.94\right)$. 


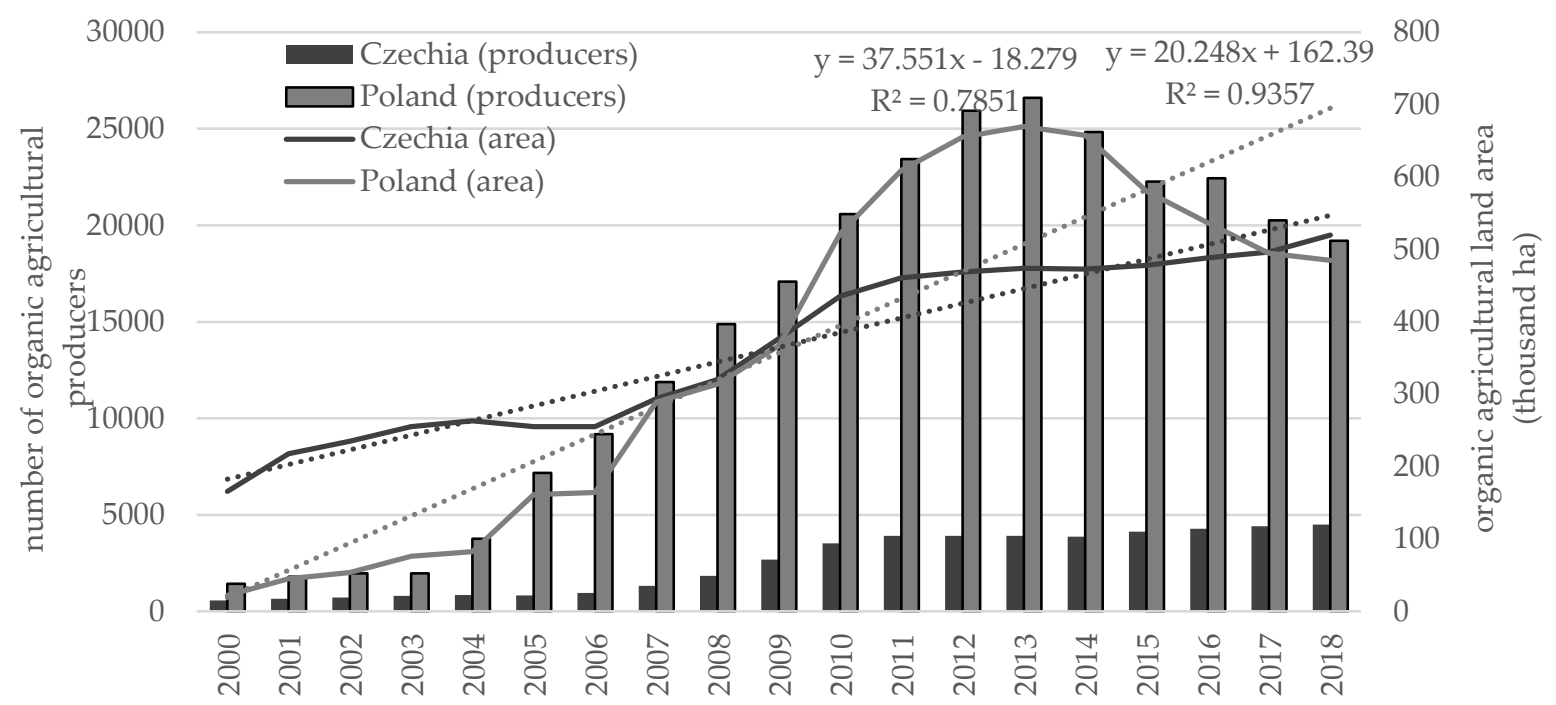

Figure 1. Area and number of producers of organic agricultural land in Poland and the Czech Republic in 2000-2018 (number, thousand ha).

The analysis of farms engaged in the cultivation of organic food in the discussed countries varied. The largest number of organic producers in the entire analysed period was observed in Poland, where it was 19,207 in 2018. The largest number of organic farms in Poland was recorded in $2013(26,598)$. After this period, their number has begun gradually decreased. Over 5 years, their number decreased by $28 \%$, i.e. by 7,391 farms. In 10-year period (2003-2013) the number of entities operating organic farms increased 12 times. In turn, throughout the whole considered period it was a 12.5 fold increase; annually by approximately 1,465 producers $\left(R^{2}=0.796\right)$. The number of organic farms in the Czech Republic was much lower than in Poland. In the Czech Republic, it was 3,929 in 2018, while their number increased almost 7 times in the whole analysed period (i.e. by 3,937 producers), or in other words by 269 farms per year (with a very good fit of the $\mathrm{R}^{2}$ trendline $=0.912$ ).

The share of the area occupied by organic crops in the total area of arable land was also estimated (Fig. 2). The data obtained indicate that Poland has a much larger total area of the agricultural land than the Czech Republic. In 2018, the area of arable land in Poland amounted to 14.7 million ha, while in the Czech Republic it was 3.5 times smaller (4.2 million ha). However, the share of the area occupied by organic farming in Poland was almost 4.5 times smaller than in the Czech Republic.

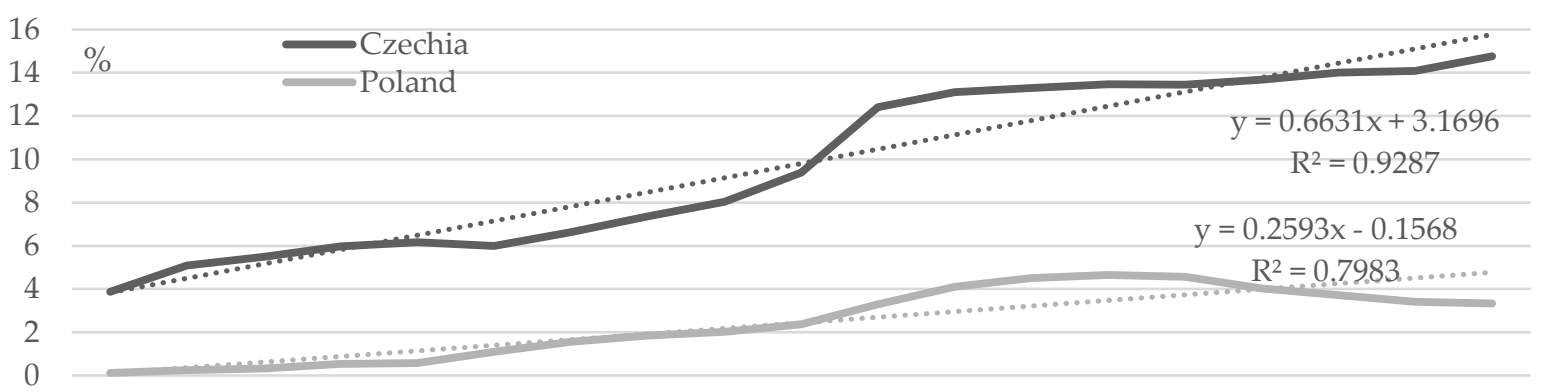

2000200120022003200420052006200720082009201020112012201320142015201620172018

Figure 2. Share of organic farming area in Poland and the Czech Republic in 2000-2018 (\% of UAA).

In the Czech Republic, organic farming area in 2018 represented almost $15 \%$ of the total agricultural area. In 2000-2018, this share increased by almost $11 \%$, and the average annual growth in the area of organic farming was $0.66 \%$. In Poland, the share of organic farming area in the total utilized agricultural area was significantly lower than in the Czech Republic. In this country, the area of organic farming covered only 3.33\% of agricultural land in 2018. Over 19 analyzed years this area increased only by $3.21 \%$, and the average annual growth in the area used for organic farming in Poland is $0.26 \%$. 
The fit of the trend line for both the Czech Republic and Poland was very good (it was $\mathrm{R}^{2}=0.93$ and $\mathrm{R}^{2}=0.80$ respectively).

The changes in the number of processors of organic products and their average number per one agricultural holding in the discussed countries were also analysed (Fig. 3). In the turn of 2000-2018, the number of ecological processing plants increased significantly both in the Czech Republic and in Poland. In the analysed period, their number grew more than 69 times in Poland, and more than 11 times in the Czech Republic. In Poland, their number has increased every year on average by 46 processing plants $\left(R^{2}=0.89\right)$, while in the Czech Republic by $38\left(R^{2}=0.97\right)$.

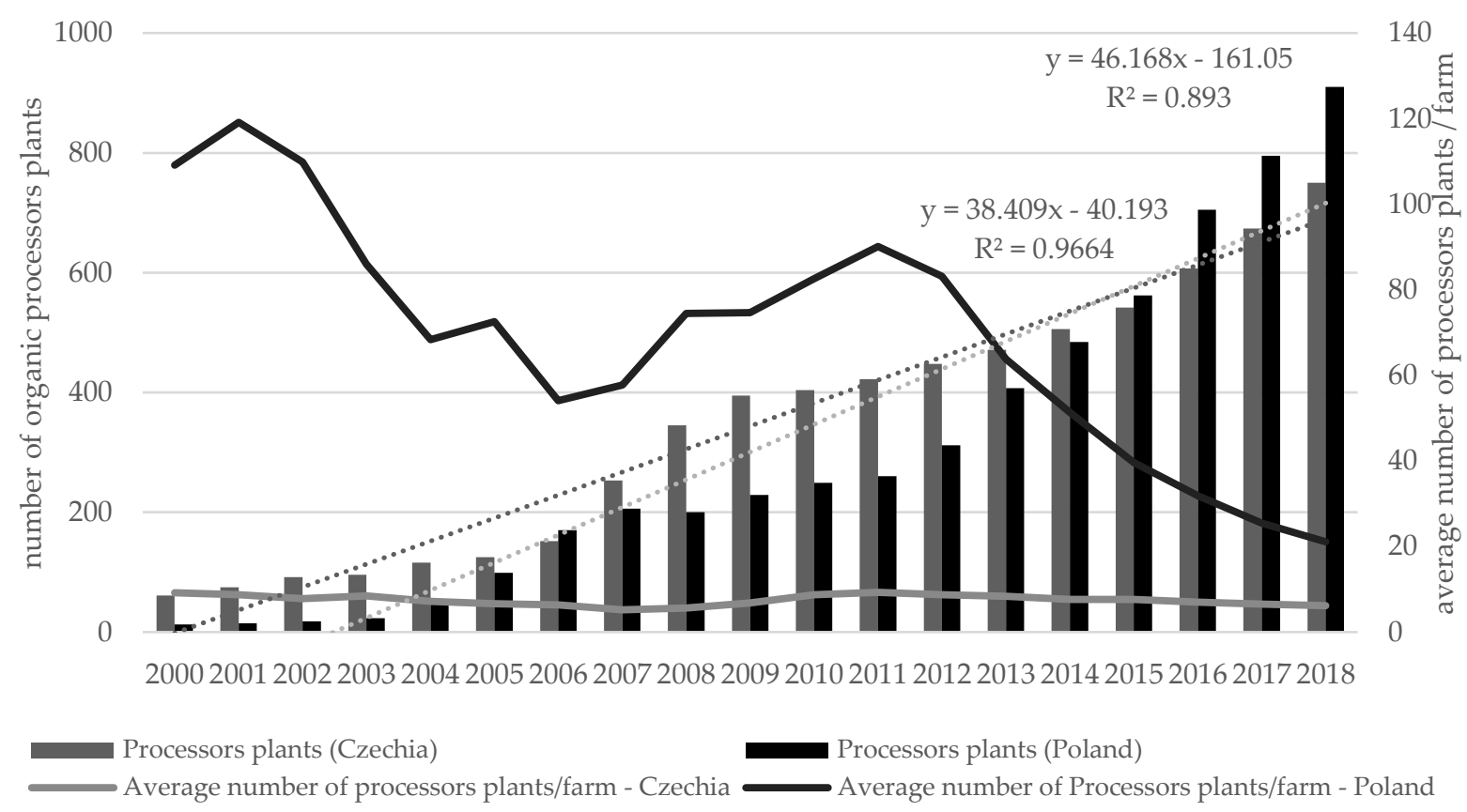

Figure 3. Processors plants and average number of processors plants per organic farm in 2000-2018.

Analysis of data on the number of processors showed that their growth was much smaller than that of agricultural producers in the analysed period. A significant problem with the lack of processors was particularly visible in Poland, where there was on average one processor per 119 organic farms in 2001. From 2001 to 2006, a downward trend was visible, indicating that the number of organic processors was increasing at a higher rate than the number of agricultural producers. Another significant increase in the number of producers per one processor was visible in the years 2006-2011. In 2011, there were on average 90 farms per one processor in Poland. Such a small number of processors contributed to the resignation of many farmers on running organic holdings, as the lack of the possibility of processing the perishable raw material, and the low interest of Polish consumers in organic products (caused by their high prices) do not encourage this business activity. This has been visible since 2011, with a downward trend in Poland related to the number of organic farms per one processor. It led to a greater extent by the systematically decreasing number of organic farms than by the creation of new processors in Poland. The situation is completely different in the Czech Republic, where in 2000 there were on average about 9 farms per a processor, while only 5 in 2007. Another increase in the average number of agricultural producers per one processor took place in 2007-2011. Since 2011, the Czech Republic has experienced a systematic decline in the average number of organic producers per one processor, mainly due to the emergence of new companies that are likely to see prospects for development and profits in this business.

An analysis of the average size of an organic farm in the surveyed countries showed that in 2018 the average size of organic farms in the Czech Republic was 115.5 ha, and it was 4.6 times bigger than in Poland (25.2 ha) (Fig. 4). In the years 2000-2018, the average area of an organic farm in the Czech Republic dropped by almost $61 \%$ (by 179 ha), the annual decrease in the studied years was about 
15.9 ha / farm $\left(R^{2}=0.87\right)$. In Poland, unlike the Czech Republic, the average farm area increased in the analysed period (by almost 63\%). The average size of an organic agricultural holding in Poland increased over 19 years by 9.7 ha, which gives growth of 0.055 ha annually.

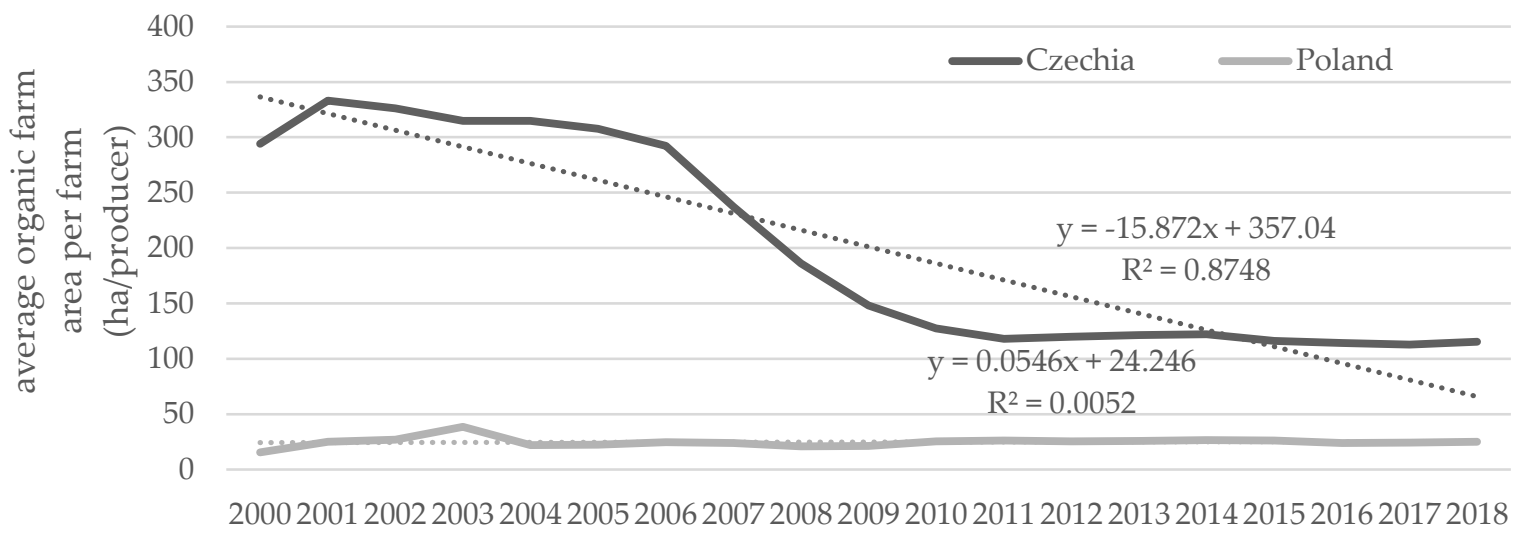

Figure 4. Changes in the average land area of an organic farm in Poland and the Czech Republic in 2000-2018 (ha/producer).

Using the Pearson's correlation coefficient, changes in average organic farm size and number of organic farms were assessed in Poland and the Czech Republic (Fig. 5).
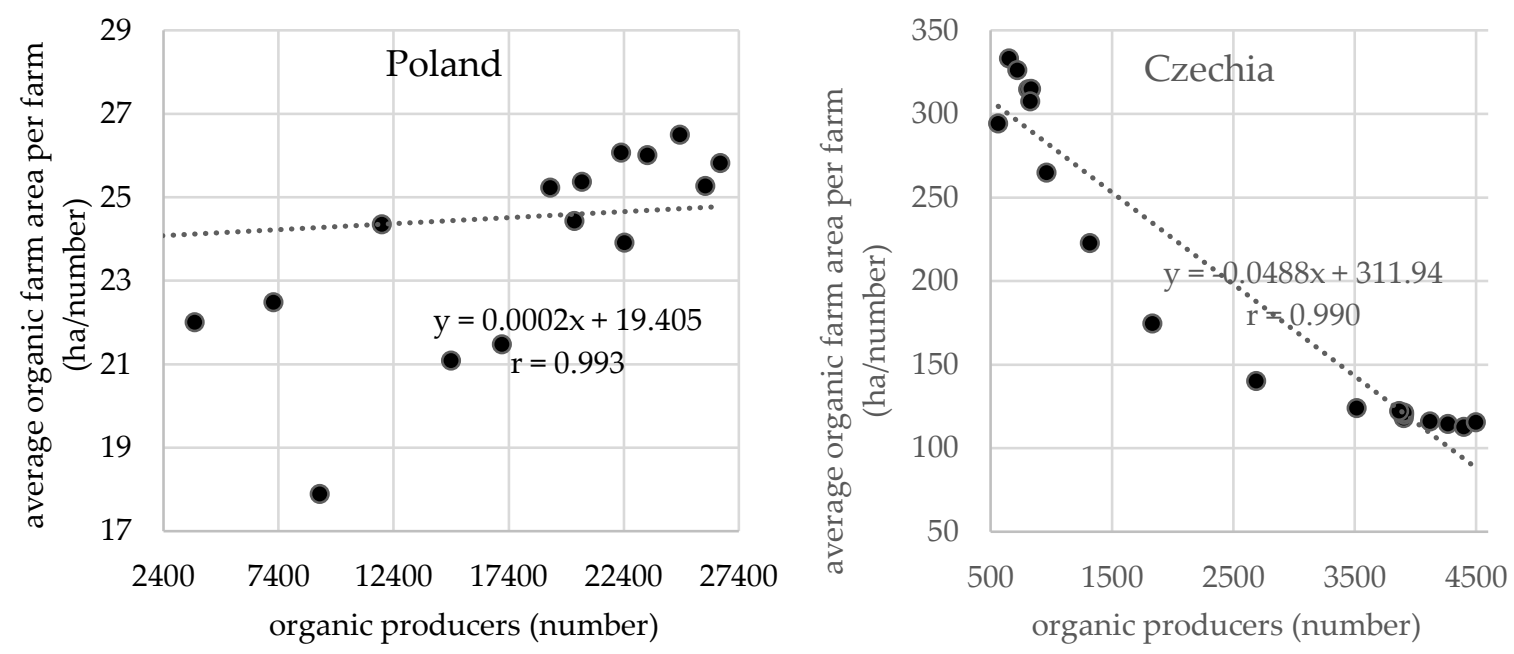

Figure 5. Correlation between the number of organic agricultural producers and the average farm area in 2000-2018 (number, ha/producer).

The analysis of the relationship between these variables showed, in the analysed years, a strong positive correlation in the case of Poland $(r=0.993)$ and a strong negative correlation in the case of the Czech Republic $(r=-0.999)$. A positive correlation in the case of Poland indicates an increase in both the average area of farms and their number, while in the case of the Czech Republic the number of organic farms grew faster than their average area. Based on these facts can be concluded that in the studied period there were new organic farms established in Poland, which increased their acreage, while the tendency to reduce the area of farms dominated in the Czech Republic.

The analysis of data regarding organic cultivation showed that same crops are cultivated in both countries, which is largely related to the geographical location, similar in the case of both countries. (Table 1). 
Table 1. Organic land area for selected crops in Poland and the Czech Republic in 2008-2017 (ha, \%).

\begin{tabular}{|c|c|c|c|c|c|c|c|c|c|c|}
\hline Specification & 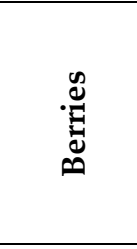 & $\frac{\infty}{\tilde{d}}$ & 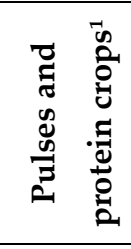 & 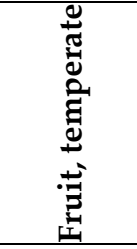 & D & $\stackrel{\infty}{\underbrace{2}_{Z}}$ & $\begin{array}{l}\frac{\infty}{\mathscr{U}} \\
\stackrel{\mathscr{W}}{0} \\
\frac{\infty}{0}\end{array}$ & $\begin{array}{l}n \\
0 \\
0 \\
0 \\
0 \\
0 \\
0\end{array}$ & 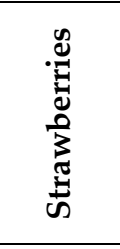 & $\begin{array}{l}\frac{0}{\pi} \\
\frac{\pi}{0} \\
\stackrel{0}{0} \\
\stackrel{0}{0} \\
>\end{array}$ \\
\hline \multicolumn{11}{|c|}{ Poland } \\
\hline 2008 & $13,322.0$ & $62,845.0$ & $3,681.0$ & $6,208.0$ & no data * & $39,300.0$ & $1,397.0$ & $1,951.0$ & $1,020.0$ & $1,544.0$ \\
\hline 2009 & $7, .930 .0$ & $77,473.0$ & $3,993.0$ & $6,709.0$ & 14.0 & $16,729.0$ & $1,465.0$ & $1,969.0$ & $1,078.0$ & $1,132.0$ \\
\hline 2010 & $10,350.0$ & $102,274.0$ & $8,338.0$ & $17,547.0$ & 96.0 & $33,114.0$ & $2,381.0$ & $2,338.0$ & $1,021.0$ & $1,761.0$ \\
\hline 2011 & $11,971.0$ & $109,511.0$ & $9,591.0$ & $36,792.0$ & 22.0 & $22,028.0$ & $1,315.0$ & $2,617.0$ & 867.0 & $1,967.0$ \\
\hline 2012 & $14,633.0$ & $122,818.0$ & $12,252.0$ & $41,990.0$ & 35.0 & $1,152.0$ & $1,573.0$ & $2,780.0$ & 904.0 & $2,825.0$ \\
\hline 2013 & $15,052.0$ & $123,229.4$ & $17,670.3$ & $45,553.7$ & 209.1 & $1,642.2$ & $2,002.1$ & $3,100.9$ & $1,280.7$ & $13,105.0$ \\
\hline 2014 & $14,270.0$ & $111,506.1$ & $23,603.6$ & $41,325.7$ & 245.6 & $1,602.6$ & $1,031.7$ & $3,015.8$ & $1,335.7$ & $9,977.4$ \\
\hline 2015 & $13,395.0$ & $101,436.0$ & $44,066.0$ & $30,401.0$ & 278.0 & $1,432.0$ & $1,820.0$ & $2,393.0$ & $1,255.0$ & $6,901.0$ \\
\hline 2016 & $14,391.0$ & $101,148.0$ & $55,968.0$ & $18,616.0$ & 258.0 & $1,200.0$ & $2,802.0$ & $2,232.0$ & $1,264.0$ & $8,071.0$ \\
\hline 2017 & $14,886.8$ & $116,083.1$ & $43,372.7$ & $10,573.9$ & 289.3 & $1,203.6$ & $4,084.3$ & $1,946.6$ & $1,254.0$ & $10,236.1$ \\
\hline $\begin{array}{c}\text { Change 2008- } \\
\text { 2017(\%) }\end{array}$ & 11.7 & 84.7 & $1,078.3$ & 70.3 & $1,966.7$ & -96.9 & 192.4 & -0.2 & 22.9 & 563.0 \\
\hline $\mathrm{R}^{2}$ & 0.42 & 0.38 & 0.85 & 0.06 & 0.84 & 0.68 & 0.38 & 0.02 & 0.47 & 0.60 \\
\hline $\begin{array}{c}\text { Average } \\
\text { annual change } \\
\text { (ha) }\end{array}$ & 496.1 & $3,921.7$ & $5,740.3$ & $1,236.8$ & 36.8 & $-4,065.3$ & 183.8 & 21.8 & 38.5 & $1,132.2$ \\
\hline \multicolumn{11}{|c|}{ Czech Republic } \\
\hline 2008 & 211.9 & $18,566.7$ & $1,293.0$ & $2,526.2$ & 341.0 & 17.6 & $1,147.2$ & 245.9 & 2.4 & 315.3 \\
\hline 2009 & 342.0 & $24,535.0$ & $1,462.0$ & $3,173.0$ & 645.0 & 57.0 & $1,191.0$ & 256.0 & 8.0 & 501.0 \\
\hline 2010 & 379.0 & $24,485.0$ & $1,785.0$ & $4,308.0$ & 770.0 & 136.0 & $2,303.0$ & 283.0 & 7.0 & $1,025.0$ \\
\hline 2011 & 484.7 & $24,381.6$ & $1,845.0$ & $5,683.8$ & 978.3 & 140.5 & $2,319.3$ & 288.6 & 5.6 & 738.7 \\
\hline 2012 & 585.7 & $27,444.2$ & $2,368.7$ & $5,917.8$ & 869.9 & 170.4 & $1,985.7$ & 270.1 & 5.8 & 454.4 \\
\hline 2013 & 475.7 & $25,883.9$ & $1,944.3$ & $5,998.2$ & $1,004.5$ & 178.4 & $1,736.6$ & 270.7 & 3.6 & 167.5 \\
\hline 2014 & 554.4 & $24,255.4$ & $1,893.2$ & $4,845.5$ & 881.3 & 97.6 & $2,045.8$ & 262.2 & 4.4 & 110.4 \\
\hline 2015 & 369.0 & $27,904.0$ & $2,300.6$ & $4,740.0$ & $1,021.0$ & 146.0 & $2,056.0$ & 247.0 & 9.0 & 225.7 \\
\hline 2016 & 305.0 & $27,633.0$ & $2,632.7$ & $4,106.0$ & 885.0 & 171.0 & $2,000.0$ & 233.0 & 3.0 & 185.9 \\
\hline 2017 & 323.1 & $29,482.9$ & $3,455.1$ & $4,435.0$ & 787.9 & 188.9 & $1,322.1$ & 285.7 & 4.0 & 248.3 \\
\hline $\begin{array}{c}\text { Change 2008- } \\
\text { 2017(\%) }\end{array}$ & 52.5 & 58.8 & 167.2 & 75.6 & 131.1 & 976.1 & 15.2 & 16.2 & 63.2 & -21.3 \\
\hline $\mathrm{R}^{2}$ & 0.02 & 0.67 & 0.77 & 0.14 & 0.38 & 0.55 & 0.04 & 0.00 & 0.02 & 0.32 \\
\hline $\begin{array}{c}\text { Average } \\
\text { annual change } \\
\text { (ha) }\end{array}$ & 4.8 & 818.7 & 181.5 & 142.0 & 41.2 & 13.8 & 29.9 & -0.4 & -0.1 & -54.4 \\
\hline
\end{tabular}

${ }^{1}$ for the production of grain

* no data available - analysis since 2009 
In Poland, as well as in the Czech Republic, cereals occupy the largest area under organic farming. It was almost 116.1 thousand ha in 2017 in Poland, while less than 29.5 thousand ha in the Czech Republic. Over 10 years, the area under cereal crops increased in Poland by $85 \%$, while in the Czech Republic by almost $59 \%$. In Poland, large crop areas were also occupied by dry legumes and highprotein plants (43.4 thousand ha), berries (14.9 thousand ha), fruit (10.6 thousand ha) and vegetables (10.2 thousand ha) in 2017. In contrast, the highest dynamics of acreage growth during the 10 years studied was recorded in the case of growing grapes (almost 20-fold) and dry legumes and high-protein plants (almost 11-fold). However, the decrease in crop area was recorded in the case of nuts $(-96.9 \%)$ and root crops $(-0.2 \%)$. In the Czech Republic, in addition to the already mentioned cereals, the largest were the crops of dry legumes and high-protein plants ( 3.46 thousand ha) and fruit (4.44 thousand ha) in 2017, while the largest increase in the cultivated area (almost 10-fold) during the analysed period related to nuts. On the other hand, the area of vegetable cultivation was significantly reduced (by 1/5).

The value of food sales on the Polish and Czech market was also assessed (Fig. 6). In 2017, the value of the organic food market in Poland amounted to EUR 235 million, while it was EUR 93.6 million in the Czech Republic.

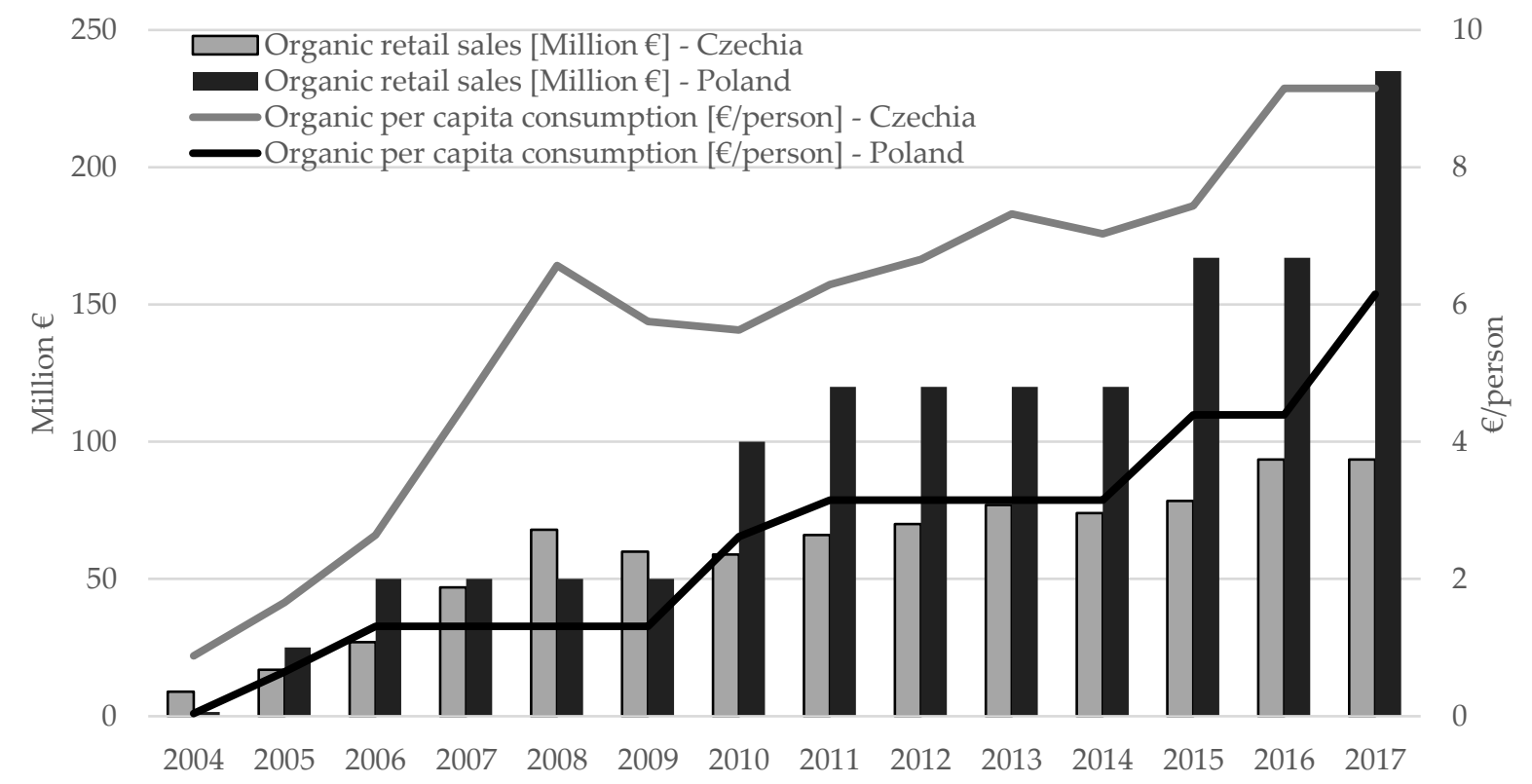

Figure 6. Organic food sales value in Poland and the Czech Republic in 2004-2017 (million €, €/person).

In the years 2004-2017, the value of this market increased almost 148 times in the case of Poland, annually it was an increase by 15 million EUR on average (with a fit at a high level of 0.92). On the other hand, , it was a 9-fold growth in the case of the Czech Republic, where the average annual value of this market increased by 5.9 million EUR (a fit of the trend line at a high level of 0.88). Despite the high value of organic food sales in Poland, when calculating this value per capita, we note that an average Czech spent more on organic food than a Pole. In 2017, a Czech resident spent on average 9.15 EUR on organic products, while an average Polish citizen expenses amounted to 6.15 EUR. However, the analysis of growth dynamics in the years 2004-2017 showed that the value of organic food sales per capita grew faster in Poland than in the Czech Republic in the studied period. In Poland, over 14 years it was almost 153-fold increase (from 0.04 to 6.15 euros), while in the Czech Republic 11-fold (from 0.88 to 9.15 euros).

\section{Conclusions}

Poland, despite a larger utilised agricultural area than the Czech Republic, has a significantly smaller share of organic farming. In 2018, the share of organic farming area in Poland was only $3.3 \%$ of arable land, while in the Czech Republic it was nearly $15 \%$. 
In the Czech Republic, a growing interest of agricultural producers in converting their holdings to organic farming is evident throughout the entire analysed period. In the Czech Republic, both the crop area and the number of producers and processors of organic food increased, while in Poland has been visible a systematic decrease in the area of crops and the number of organic producers since 2014 . In Poland, in the whole analysed period, increased only the number of organic food processors, although for many years they were a bottleneck in the national organic food distribution channel. And yet food, not only organic, belongs to perishable and seasonal products, so that to be available on the market throughout the year, it requires appropriate processing.

The resignation of many Polish farmers from conducting organic agricultural holdings was, to a large extent, a consequence of growing uncertainty among them as to the requirements related to running organic farms and subsidies received from the state. There have been changes in regulations regarding procedures and rules for providing assistance to organic food producers in Poland since 2014. Over a 5-year period (2014-2018), they changed seven times. These changes were the reason for delays in issuing subsidies to organic farmers (the so-called ecological payments) and, consequently, also in the payment of funds allocated. Another reason for the resignation of Polish farmers from running organic farms were the growing requirements for the harvested crops. According to the regulations, an organic producer should at least $80 \%$ of his production allocate for sale or processing. Some of these regulations contributed to the elimination of farmers who were not engaged in production for the market but only collecting subsidies. However, such excessive commitments meant that many organic farms lacked produce to feed their own animals (which then had to be bought by the farmers). The farmer might also have problems selling organic products on the increasingly competitive organic food market. High prices of organic products also mean that despite the view that Polish and Czech societies are getting richer, only some of the households could afford them (the share of organic food in the food market in Poland was around $0.3 \%$, while in the Czech Republic $0.9 \%$ in 2017).

In these countries, there is a visible tendency for farmers to keep medium-sized organic farms, which is certainly dictated by the way organic farming is carried out. Therefore, there is a visible trend to reduce the area of organic farms, visible in the Czech Republic. The reasons for such situation include, among others, problems with recruiting employees as organic farming (to a greater extent than traditional agriculture) requires manual work. On the other hand, due to the small scale of production, organic farms have difficulties in achieving profitability. As Komorowska (2012) notes, the smallest farms (up to 10 ha of UAA) show the highest level of productivity of land and capital resources. With an increase in a farm size, the productivity of land and capital resources deteriorates. In smaller organic farms, the structure of arable land has a larger share of vegetable, fruit and edible potatoes, i.e. products for which farmers obtain relatively higher prices compared to the prices of conventional products, which in turn translates into their production and economic results.

Consumers often have a misconception about organic farming as it seems to them that organic production does not require any activities (no spraying, fertilizers, etc.), everything grows by itself. Therefore, according to them, such products should be cheaper. In fact, in organic farming, specialized and natural fertilizers are used, which means high costs. As emphasized by the expert of the Polish Chamber of Organic Food, an important barrier to the development of organic farming is the fact that the conversion of a farm into organic production is a long process that takes about three years. During this time, additional high costs must be incurred and stringent standards must be met in order to obtain eco-certification. It is only after this period that a certificate is obtained and organic products can be sold. The farmers, all the time, need to work on the soil, to improve the humus content of the soil, apply green manure (after harvesting, it is necessary to sow plants that build humus), add natural fertilizers, which are more expensive. It requires a lot of work with the soil to make it live, adding soil microorganisms, etc. All of this is of great importance if high-quality crops are to be achieved. 


\section{References}

Barłowska Joanna., Wolanciuk Anna, and Idec Justyna. 2017. Rolnictwo ekologiczne w Polsce na tle Unii Europejskiej i świata. Przeglad Hodowlany: 2, 1-4.

Eurostat. 2019. Farm structure. Available online: https://ec.europa.eu/eurostat/data/database (accessed on 12 January 2020).

Kiełbasa Magdalena. (2015). Przyszłość sektora rolno-spożywczego w Polsce w odniesieniu do stanu obecnego. Progress in Economic Sciences: 2, 227-230. https://doi.org/10.14595/PES/02/016.

Komorowska Dorota. (2012). Wielkość a Efejtywbiść Gospodartw Ekologicznych. Zagadnienia Ekonomiki Rolnej: 4 (333), 65-83.

Kowalska S. Anna, and Kovárník Jaroslav. 2019. Smart specializations in Poland and the Czech Republic. Paper presented at the Hradec Economic Days 2019, Hradec Králové, Czech Republic, February 5-6, pp. 447-457. Available online: https:/uni.uhk.cz/hed/site/assets/files/1073/proceedings_2019_1-1.pdf (accessed on 15th January 2020).

Kowalska S. Anna, Tarnowska Agnieszka, and Kovárník Jaroslav. 2017. Polish - Czech trade in agri-food products before and after accession to the European Union. Paper presented at the Hradec Economic Days 2017, Hradec Králové, Czech Republic, February 5-6, pp. 497-459. Available online: https://uni.uhk.cz/hed/site/assets/files/1046/proceedings_2017_1.pdf (accessed on 15th January 2020).

Łapińska Justyna. 2011. Breaches of the organic agriculture principles in the Czech Republic. Zeszyty Naukowe SGGW w Warszawie - Problemy Rolnictwa Światowego: 11(26), 78-85.

Ministry of Agriculture of the Czech Republic. 2017. Yearbook 2016: Ecological Agriculture in the Czech Republic. Prague: Ministry of Agriculture of the Czech Republic.

Ministry of Agriculture of the Czech Republic. 2018. Yearbook 2017: Ecological Agriculture in the Czech Republic. Prague: Ministry of Agriculture of the Czech Republic.

Ministry of Agriculture of the Czech Republic. 2019. Yearbook 2018: Ecological Agriculture in the Czech Republic. Prague: Ministry of Agriculture of the Czech Republic.

Olszańska Anna, and Dittrichová Jaroslava. 2018. Direction of Changes on the Milk Markets in Poland, the Czech Republic and Slovakia in comparison with the Biggest Milk Producers in EU (2005-2016). Paper presented at the Hradec Economic Days 2017, Hradec Králové, Czech Republic, February 5-6, pp. 92-101. Available online: https://uni.uhk.cz/hed/site/assets/files/1072/proceedings_2018_1.pdf (accessed on 17th January 2020).

Research Institute of Organic Agriculture. 2019. European and Global Organic Farming Statistics. Available online: https://statistics.fibl.org (accessed on 10th January 2020).

Rigby Dan, Câceres M. Daniel. 2001. Organic farming and the sustainability of agricultural systems. Agricultural Systems: 68, 21-40. https://doi.org/10.1016/S0308-521X(00)00060-3.

The International Federation of Organic Agriculture Movements. 2005. The IFOAM norms for organic production and processing. Available online: http://www.ifoam-eu.org/ (accessed on 10th January 2020).

The International Federation of Organic Agriculture Movements. 2019. Annual Reports. Available online: http://www.ifoam-eu.org/ (accessed on 10th January 2020). 